their habits, and their mode of penetrating the body ; up to this time man was conquered by these in finitesimal beings, but, thanks to recent discoveries, he will be their conqueror. When, at the beginning of a century, one can inscribe the name of Jenner, and at its end that of Pasteur, the human race may rejoice. More has been done for it against misery, disease, and death than in any one of the centuries which have preceded it. You, gentlemen, you have been the initiators; this title will never be disputed with you. When a great people has given such an example; when, by her gracious patronage, Her Majesty the Queen, and when, by his presence, His Royal Highness the Prince of Wales, testify that for them this era of reforms is not closed, it is only right that those who try to imitate them, and to give their country similar institutions, should come to bring to that people, and to their Sovereign, the homage of their profound respect."

Dr. Van Coler, the Medical Director-General of the Prussian Army, the representative of the German Government, followed suit, and showed the aid rendered to armies by the improvements in sanitary science. We give the following short extracts from his speech :-

"It is indeed with a feeling of joyous pride that from this place and in this country, where we have to trace the very cradle of all modern science of public health, I am permitted to point out how the many efforts made in the direction of hygiene radiating from England were, especially in Germany, hailed with much delight ; where they received the most careful attention, and where they ever since have been most actively promoted. . . . If from our army, diseases like malaria, small-pox, dysentery, have completely, or almost completely, disappeared ; if typhus fever and diphtheria become more and more diseases of the past, we have to be thankful for these attainments to the development and application of hygiene. ... It is now an established fact that infectious diseases are by no means a necessary evil in the army. They are simply diseases which can be avoided, which can be powerfully opposed, and against which the science of our days battles victoriously with ever-increasing success."

Dr. Körösi's address will be welcome to many, as he exactly defined demography - which is a puzzle to many outsiders-and pointed out the early work done by members of the Royal Society :-

"This branch of science, the very nucleus of statistical work, which, in fact, is quite a science in its own right, has chosen the task to investigate the laws which regulate the life, increase, and decrease of nations. Its work, therefore, comprises three main parts: statistics of natality, of mortality (this part including biometry, the science of measuring the duration of human life), and of the increase of population. And when inquiring now who were the founders of this new science, we shall hear unanimously quoted the names of England's sonsGraunt, Petty, Halley, Malthus. Gentlemen, to-morrow, when we are to begin our work, we shall meet within the venerable hall of the Royal Society. The representatives of demography must feel a deep emotion when entering those rooms, which are so intimately connected with the history of their science, for this is the place where, 220 years ago, demography was created. It was in those halls, in their very first youth then, but soon conspicuous to the whole world by the genius of Newton, that appeared the work of Graunt which forms the startingpoint of demography; and here the King himself, admirably appreciating the work done, recommended the author to be received as a member of the learned Society. It was there that shortly afterwards Sir William Petty, by his eminent power, raised the new science to political importance and to popularity, and in the same place, again, in 1693, the famous Halley became the founder of the most important part of demography, of biometry, by working out the first table of mortality. And now the young science, which two centuries ago left those halls shy and even without a name, has found its way over the whole globe. Having been worked out in Germany, having received a name and new ideas in France, and having been enlarged and imbued with a more scientific character by Quetelet, having got its well-equipj ed office in every country of the civilized world, we are roud to see now its numerous representatives meet at the same place where two centuries ago this science was born. After a triumphant career of 220 years, it returns to its home, to the old rooms in which it awoke to light, and again the Throne of England receives it with favour and benevolent interest. For demography not less than for all statistical work, it is of the highest importance that its representatives, scattered as they are over the whole globe, should fully understand each other, for only so we can accomplish our aim, that our observations comprise equally all countries of the world, that our researches are conducted and worked out on the same principles everywhere, and that we may unite the incomplete and often discrepant descriptions of the single nations to a full descriptive history of the whole of civilized mankind. This great aim fully deserves the praise the illustrious Prince Consort bestowed upon it from this very place thirty years ago. He said, "The importance of the Congresses cannot be over-rated; they not only awaken public attention to the value of these pursuits, bring together men of all countries who devote their lives to them, and who are thus enabled to exchange their thoughts and varied experiences, but they pave the way to an agreement among different Governments and nations to follow up these common inquiries in a common spirit by a common method and for a common end.'"

The meeting was subsequently addressed by Sir James Paget, Dr. G. Buchanan (of the Local Government Board), and others.

The Sectional work of the Congress began on Tuesday. The Divisions and Sections are as follow :-

Division I.-Section I. Preventive Medicine. President, Sir Joseph Fayrer, K.C.S.I.-Section 2. Bacteriology. President, Sir Joseph Lister, Bart.-Section 3. The Relation of the Diseases of Animals to those of Man. - Section 4. Infancy, Childhood, and School Life.Section 5. Chemistry and Physics in Relation to Hygiene. President, Sir Henry Roscoe, M.P.-Section 6. Architecture in Relation to Hygiene. President, Sir Arthur W. Blomfield, A.R.A.-Section 7. Engineering in Relation to Hygiene. President, Sir John Coode, K.C.M.G.Section 8. Naval and Military Hygiene. President, Lord Wantage, K.C.B., V.C.-Section 9. State Hygiene. President, Lo:d Basing.

Division II.-Demography. President, Mr. Francis Galton.

We shall endeavour next week to give an idea of the results of the many important discussions which may be anticipated, but it is already clear that it will be impossible for us to give anything like a full report, for the programme of work to be gone through is enormous. The addresses of the various presidents on the opening day were in themselves important communications, and well fitted to give tone to the subsequent discussions.

\section{PROGRAMME OF TECHNOLOGICAL} EXAMINATIONS.

A SIGN of the general advance in technical education is shown in the new Programme of Technological Examinations just published by the City and Guilds of London Institute. The Programme contains 37 pages of additional matter, and the number of different subjects of examination has now reached sixty. The Council appear to be genuinely desirous of adapting the examinations to the conditions of the more important trades as practised in the principal centres of industry. To this end, many 
of the sixty subjects are divided into different sections, corresponding to the separate branches of the same trade, or to the practice of the trade in separate localities.

In the new Programme we notice many important additions. A practical test, which is the surest preventive of cram, and excludes those who are not engaged in the trade from presenting themselves for examination, has been added to the syllabus of nearly all the subjects, Thus, next year, for the first time, there will be practical examinations in such widely different subjects as photography and boot and shoe manufacture. In many subjects dealing largely with the practical applications of science the syllabus has been entirely re-written. This is the case with "Electrical Engineering," which is now divided into two main subjects-"Telegraphy" and "The Transmission of Power"-the former being again subdivided, in the honours grade, into "Telegraphy" and "Telephony," and the latter into "Electrical Instruments," "Electric Lighting," and "Dynamos, Motors, \&c." The subject of "Mechanical Engineering" is similarly divided into different sections. The Programme has been increased by the addition of a syllabus of instruction in " Goldsmiths' Work," in which subject a large class has been already established in Birmingham, and of a syllabus in "Ship Carpentry and Joinery," which is intended to meet the requirements of artisans engage 1 in the different shipbuilding yards throughout the country.

The continuous increase in the number of candidates for these examinations, and in the number of students receiving instruction in the different centres throughout the country, shows that there is a genuine demand among artisans for practical and concrete instruction dealing, in the first place, with the facts with which they are familiar in their every-day work, and, afterwards, with the scientific principles explanatory of those facts. From the table found on p. I 7 of the Programme, it appears that this year 7322 candidates presented themselves, as against 6667 in the previous year, and that the number of students under instruction increased from 12,022 to I3, 202 .

The memorandum issued to County Councils, to which we have already referred in these columns, is re-published in the Programme. It draws the attention of County and Borough Councils to the fact that, after the examination in May I892, the grants hitherto paid on the results of the examination will be withdrawn, and that a substantial portion of the funds thus set free will be devoted to the improvement of the machinery of the examinations. Indications of the direction in which these improvements will be made will be found in the new Programme. It is important that the managers of technical classes should fully understand that, in future, the maintenance of such classes will depend entirely on local support. The large sums placed at the disposal of County Councils clearly render it no longer necessary that the City Guilds Institute should continue to make grants on results, which, although amounting in the aggregate to a large sum of money, proved to be quite inadequate to properly support the classes. It is, however, to be feared that the grant-earning tendency of the teachers and managers of local schools may cause the distinctly technological subjects of instruction to be neglected for the sake of science subjects by which grants may still be obtained from South Kensington. To prevent this, it is necessary that County Councils should realize the full importance of the work which Parliament has thrown upon them, and should recognize that in future they will be the authorities responsible for the conduct of the technical and, indeed, the secondary education also of the county. In the competition for money grants, technical subjects will be placed at a distinct disadvantage as compared with ordinary science subjects, and it is the more necessary, therefore, that the teaching of these subjects should receive adequate support from local authorities.

In order that the teaching in different localities may be duly adapted to the trades practised in those localities, and may be regulated by these requirements, and not by the grant-earning capacity of the subjects of instruction. it is very desirable that County Councils should organize, independently, or in connection with the City Guilds Institute, a system of inspection of local classes. The value of examinations is immeasurably increased when they are supplemented by inspection by competent experts, and it is to be hoped that some system of inspection of technical schools, which shall include the methods of instruction adopted, will soon be organized.

The Institute's Programme offers to different localities a wide choice of trade subjects, ranging from simple handicrafts to industries involving some of the most difficult applications of physical and chemical science. To the syllabus of each subject is added a valuable list of works of reference, which forms by itself a very complete guide to books in technology. The list of examiners, many of whom have this year been newly appointed, includes well-known experts in each branch of trade, and is a guarantee of the efficiency of the examinations. The future development of technical education is now very largely under the control of County Councils. They possess the funds without which no real progress can be made. But, besides funds, experience and organization are needed, and there can be no doubt that the members of County and Borough Councils will derive much valu. able information, and many serviceable suggestions, from the new edition of the City Guilds Institute's Programme of Technological Examinations.

\section{BOTANICAL SLRVEY OF INDIA.}

THE organization of a Botanical Survey of India, which has been under consideration since 1885 , has been finally settled by the following resolution of the Government of India, dated Calcutta, February 26, I 89 I :-

(I) The scheme for carrying out the botanical survey of India, which has been under consideration for some time, was finally completed a year ago, and His Excellency the Governor-General in Council considers that it is now desirable to publish the details for the general information of local Governments and Administrations.

(2) In February I 885 , Mr. Thiselton Dyer, Director of the Royal Gardens at Kew, prepared for the Government of Madras a Memorandum on the constitution of a Botanical Department for the Madras Presidency, one result of which was the eventual establishment of a Botanical Department for that Presidency. In sanctioning the Madras Department, the Secretary of State for India took the opportunity to suggest for the consideration of the Government of India whether, without interfering with the control exercised by the Provincial Governments, it would not be possible to bring into communication the various Botanical Departments of the different Provinces, the desirability of such an association having been prominently noticed by Mr. Thiselton Dyer in his Memorandum of February 1885 . The wider scheme thus suggested by the Secretary of State was accordingly considered; and the first step taken for the organization of a Botanical Survey for all India, which was to have its centre in the Royal Botanical Gardens at Seebpur, Calcutta, was the transfer from the control of the Government of the North.Western Provinces and Oudh, to that of the Government of India, of the Superintendent of the Botanical Gardens at Saharanpur. This measure was demanded by the need for botanical survey in the Punjab, Rajputana, Central India, and the Central Provinces, which had hitherto been unrepresented by any 